\title{
Diagnosis of the public water supply in the city of Maringa, PR and its relation to the concept of smart cities
}

\author{
Roberto Takeshi Nakahashil \\ Alinor Rodrigues Júnior" \\ Bruno Henrique Toná Julianill' \\ Cristhiane Michiko Passos Okawalv
}

\begin{abstract}
With the development of cities in a more integrated and innovative management for urban sectors, the smart cities emerge, usually incorporating this evolution using the Information and Communication Technology (ICT), necessitating investments in technology and innovation in the public policies. In light of this context, the purpose of this paper was to carry out the diagnosis of the city of Maringa concerning innovation and the use of ICT in the potable water public supply sector. It was conducted interviews with the responsible for the concessionaire of the water supply in Maringa (SANEPAR), and also document evaluations. The results attest to the development of a project elaborated by SANEPAR in partnership with Parana Meteorologic System (SIMEPAR), with the intention of a more intelligent water supply system, that allows the prediction of possible floods in the water catchment plant by heavy rainfall. Thus, it can be concluded that there is the intention of implementing smart technologies, beginning with the protection to the catchment of the water, that can be extended to the operation of the whole water supply system of the municipality of Maringa.
\end{abstract}

Keywords: Smart citiesand ICT; Intelligent water supply system; Innovation in urban water management

\footnotetext{
'Graduation Student in Civil Engineering, Civil Engineering Department, State University of Maringa, Maringa, PR, Brazil. roberto.japa95@gmail.com

"Civil Engineering, Sanitation Company of Paraná, Maringa, PR, Brazil. alinorjr@gmail.com

"II Master Student of the Postgraduate Program in Water Resources and Environmental Engineering, Federal University of Paraná, Curitiba, PR, Brazil. brunotjuliani@gmail.com

IV Phd in Environmental Sciences, Civil Engineering Department, State University of Maringa, Maringa, PR, Brazil.

cmpokawa@uem.br
} 


\section{Introduction}

The United Nations estimate that from the year 2015 to 2050, the world population will increase in $32 \%$, that is, a growth from 7.2 to 9.7 billions inhabitants, while the urban population will be increased in 63\%, from 3.9 to 6.3 billions. Present assumptions suggest that until 2030 more than $60 \%$ of the world population will be located in the cities, highlighting the growth in Africa, Asia and Latin America (UNITED NATIONS, 2014; UNITED NATIONS, 2015).

This rapid transition towards a more urban population has created a scenario of multiple challenges for the planning, progression and operation of cities, creating new thinking from professionals such architects, urban planners and designers, municipal government and by information technology. The information systems have different roles for the solution and thus a closer integration between the communities must exist (HARRISON; DONNELLY, 2011).

In view of this scenario of growth, the entire globe is increasingly urban and so forth cities tend to become also more intelligent ones. The extended urbanization requires new methods, solutions and innovations to manage the existing complexity in urban life, as the super population, energy consumption, tailings management and environment protection (EREMIA; TOMA; SANDULEAC, 2017). Government should then seek out new demands for different types of actions related to the water supply, education and sustainability. Therefore, the technological development is able to help local government cope with these urban challenges, improving the town's environment and dealing with environmental risks. For the prevention and management of these risks, the cities must now innovate and become intelligent (HERNANDEZ, 2018).

In addition, urbanization holds a relationship with sustainability, which has being considered as one of the greatest challenges to be dealt with, and the concept of sustainable development increasingly applied over social, economic and ecological perspectives in societies (ELKINGTON, 1999). However, cities present most of global environmental problems on either social, economic or ecological sphere, leading to 
the necessity of the development of solutions, beginning with the transformation in the way of thinking, managing and planning urban areas (ABDALA et al., 2014).

The sustainable development, along with Information and Communication Technology (ICT), is capable of offer a higher quality of life and achieve an efficient management of natural resources, softening cities environmental issues (DURAN; PEREZ, 2015). In this perspective, a new concept of smart cities emerges, as a solution to urban challenges, from a new dimension of public governance (WEISS; BERNARDES; CONSONI, 2015).

Smart cities may be defined as cities where the ICT is used for urban development, in changing process of technology and production for the transformation and recreation of the space, in order to improve the population welfare in a more sustainable way (CURY; MARQUES, 2017). As well as raising the standard of living, according to the periodical publication Cadernos FGV Projetos (2015), a smart city increases the competitive side along the Brazilian cities and offers a major challenge to public administrators. For the progress of a smart city, integrated and innovative, it is necessary a systemic view and an effective integration among urban sectors. In order to reach these goals, investment should bemade in technological innovations and in management, planning and development of public measures.

Given this context, in January of 2016 the city of Maringa, Parana, has suffered a high intensity precipitation, and as consequence, the breakdown of the pumping station of Rio Pirapo, the source of water supply for the town, due to the floods. With the clean water supply interrupted for approximately one week, new studies were made necessary in order to determine a series of measures for this issue.

In view of the above, the objective of this paper is to conduct a diagnosis for the city of Maringa regarding the innovation and the use of ICT in the public water supply sector. 


\section{Materials and Methods}

\subsection{Characterization of study area}

The municipality of Maringa is located in the northwest of the state of Paraná, covering an area of $487,052 \mathrm{~km}^{2}$, and with a population of 357.077 inhabitants, according to IBGE 2010 data census (2017). The city was officially founded in May 10, 1947, and both foundation and planning were promoted by CompanhiaMelhoramentos Norte do Paraná (MENEGUETTI, 2009).

Regarding to the climate, according to Meneguetti (2009), the city presents the characteristics of subtropical and semi-humid climates, with the average annual temperature above $20^{\circ} \mathrm{C}$, which are higher between November and March, and lower between May and July. By its classification as a semi-humid region, the humidity range presents ah huge variation, with extreme low values in the months of July, August and September, and higher ones in the summer, standing out the month of January, period in which Maringa suffers very heavy falls of rain.

The rivers of the region are considered in most cases as rocky and with an uneven ground. The main river for the public water supply of the municipality is the Pirapo, with anextension of $150 \mathrm{~km}$, which contributes to Paranapanema river, and this one being a tributary to Paraná river.

\subsection{Characterization of research and methods}

According to Gil (2010), as it is not expected the practical implementation of the proposed subject, this present research is considered to be of a basic nature, and in addition, perform a descriptive study, not with numbers, in a qualitative way. An exploratory approach is established, from the standpoint of the final objectives, and a literature review is conducted, with an application in a study case.

The research started with the theoretical background of the concepts of smart cities, focusing in water and sanitation sectors. The goal of this step is understanding and enhancing the knowledge about the covered subject, supplementing with 
examples of smart cities in which the technology was applied in the civil engineering range in Brazil and all over the world.

Related to the data collection, it has been carried out from technical visits to the responsible concessionaire of the water supply in Maringa, and from surveys with the managers. The diagnosis of the drinking water supply management of the municipality was based in desk reviews and informal interviews with the civil engineer in charge. The observational method was applied for the data analysis, in which the researcher has visited the data centre of the company, describing the main activities and evaluating relevant graphical data.

\section{Results and Discussion}

For the diagnosis of the city of Maringa relating to water and sanitation, there was a need to implement the measures of Information and Communication Technology, in order to make the water catchment monitoring system smarter. This is due to the incident that happened in January 2016, with the occurrence of an terrific rainstorm, raising Pirapo's river water level, flooding the water catchment system and putting the drinking water supply on hold for the hole town.

In view of this accident, Parana's Sanitation Company (SANEPAR) and Parana's Meteorological System (SIMEPAR) developed a Project of an alert system for floods in the Pirapo river to make the public water supply system more intelligent and to avoid future concerns to the population. The projects initial priority was the implementation of the water catchment platform in a greater height than the the previous one of 10 meters high, and developing the automatic river water level tracking and transmission to the data centre by radio, set as shown in figure 01 .

The project presents a set of tools, as the automatic display of the fluviatile and pluviometric data monitoring, with data values of the river stream flow, precipitation and cumulative rainfall in the Pirapo's river basin, the contribution area for the basin runoff nearby Maringa's Water Treatment Plant (ETA). Another component presented in the project is the flood alert system, which performs qualitative 
forecasts, using as references subjective intuitions, experiences and opinions, and quantitative forecasts, applying historic data and a mathematical model capable of future forecasts (BONOTTO; FOGLIATTO, 2015).

Figure 01 - Location of the Water Treatment Plant (ETA) of Pirapo river, and Pirapo river basin

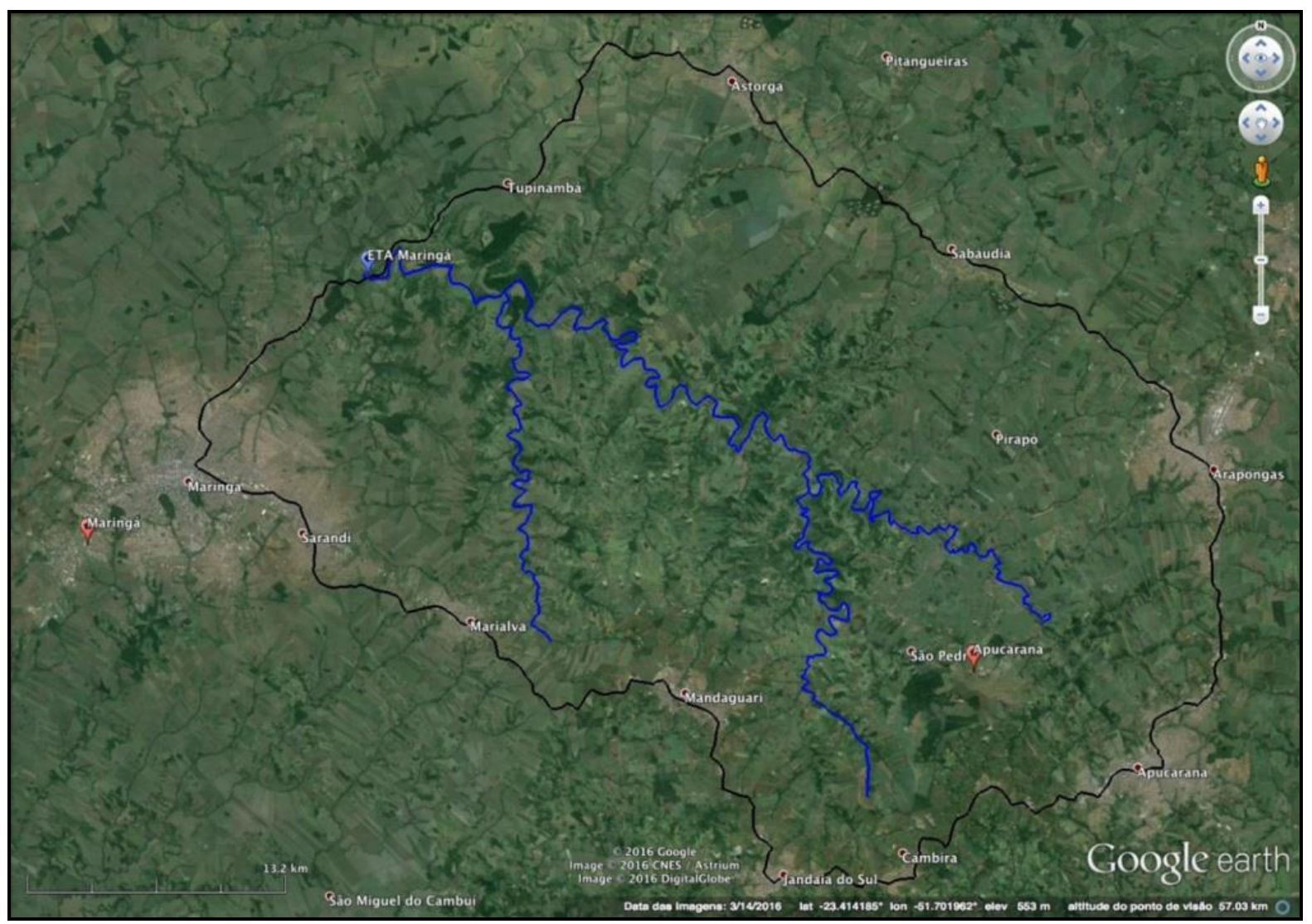

Source: SIMEPAR, 2016

Based on qualitative and quantitative forecasts, and the rainfall contribution for the river basin area is verified, with this hypothesis being executed for the following 120 hours of cumulative precipitation and river flow rate data, updated hourly. The obtained data is collected by the concessionary, by means of a sensor installed in the same section of the river where the catchment of the water is conducted, located in the coordinates $23^{\circ} 19^{\prime} 32,88^{\prime \prime} S$ and $51^{\circ} 50^{\prime} 42^{\prime \prime} \mathrm{W}$, illustrated in figure 02 .

The collected data is then applied in the development of a flow rate per time graph, according to bathymetry measurement of the transversal section, resulting in 
the river water level, besides generating a table containing observed and predicted hourly flow values.

Figure 02 - Location of the sensor installed in SANEPAR's water treatment plant, with coordinates $23^{\circ} 19^{\prime} 32,88^{\prime \prime} \mathrm{S}$ and $51^{\circ} 50^{\prime} 42^{\prime \prime} \mathrm{W}$

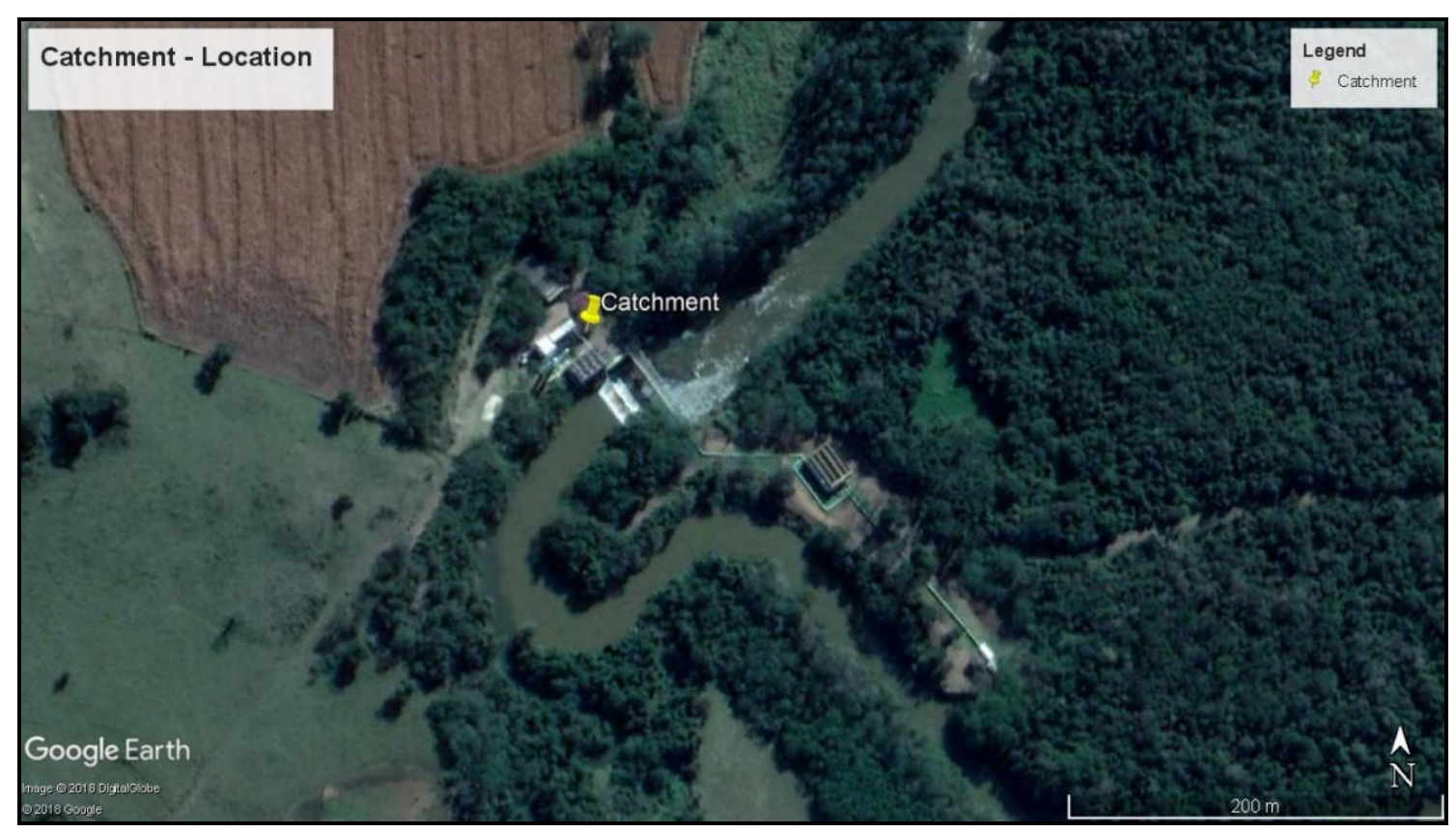

Source: Google Earth, 2018

The first step of SANEPAR's project, along with SIMEPAR, started with the hydrological data evaluation, and for this study in particular, the stream flow data from Pirapo river and a hydrological flow model elaborated from the data given. Hydrological models seek to represent the terrestrial part of the hydrological cycle, converting the precipitation over a surface into stream flow of a river, represented mathematically by the water flow over a region of a specific basin. The hydrologic modelling deals with a system of equations and parameters that are frequently used as reference of environmental studies, with the purpose of understanding the impact of the changes in the use of land and predict future changes in ecosystems (ALMEIDA; SERRA, 2017).

Defined the model, there was a need for its calibration, adjusting the parameters and adapting it to the study area, thus, performing a better representation of the observed reality. With the parameters adjusted and the 
calibration validated, the model provides cohesive output data compared to the reality of the system (SOUZA, 2016).

The pre-project phase, proposed by SIMEPAR, presents the water level data collected during the period from August 23, 2015 to June 01, 2016, by means of the sensor installed in the station for the automatic fluviatilemonitoring, and this observed data is necessary to the parameters adjustment for the hydrological model. The information is displayed in a graph form, relating the observed water level to the modelled one, combined with precipitation data, as shown in figure 03.

From Figure 03, it can be observed that observed and modelled water levels perform a similar behaviour, with a difference in the peak from 25 to $30 \mathrm{~cm}$. In addition, taking in consideration the rainfall response, there was no error in the initial project, and the model has neither advanced or delayed the time to peak of the flood. In view of the results presented by the Parana Meteorological System, the flood prediction in a river basin leads to adequate responses to the flood alert system.

Figure 03 - Observed and modelled water levels, and precipitation data for Pirapo river basin

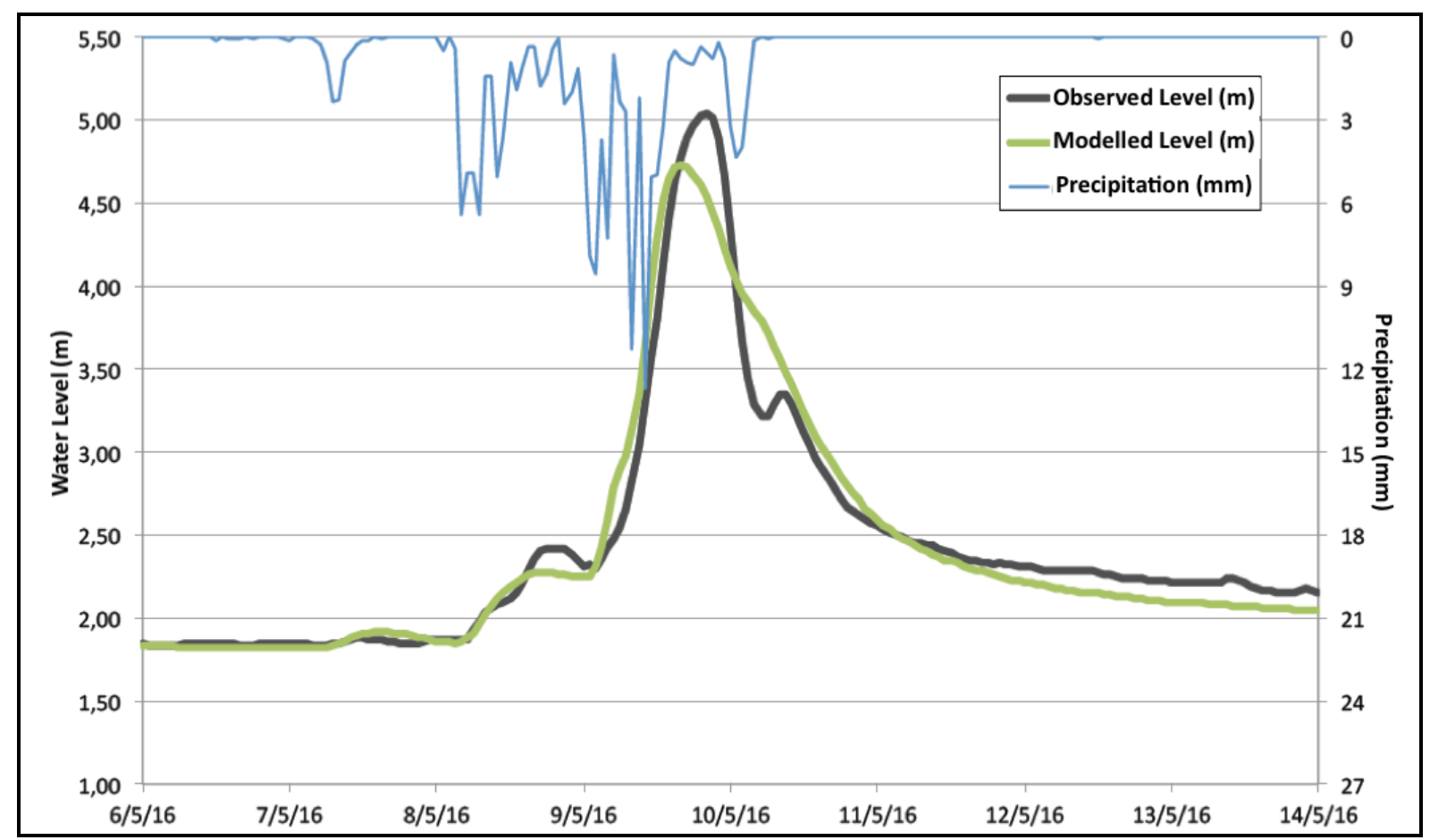

Source: SIMEPAR, 2015 
In a visit to SANEPAR treatment plant, carried out in March 2017, during the stage of development of the project, real-time flow values were being collected and with the hydrological model calibrated and validated, it was designed a graph containing the flows observed and predicted by the model, along with its respective parameters, illustrated in figure 04. For model proposed by the Hydraulic Research Institute (IPH) of Federal University of Rio Grande do Sul (UFRGS), which converts precipitation into flow, 4 parameters were defined, denominated as P1-IPH-F1-PLU, P1-IPH-F2-PLU, P1-SAC-F1-PLU and P1-SAC-F2-PLU.

Figure 04 - Representation of the observed and predicted flow data, according to the hydrological model parameters defined for the project

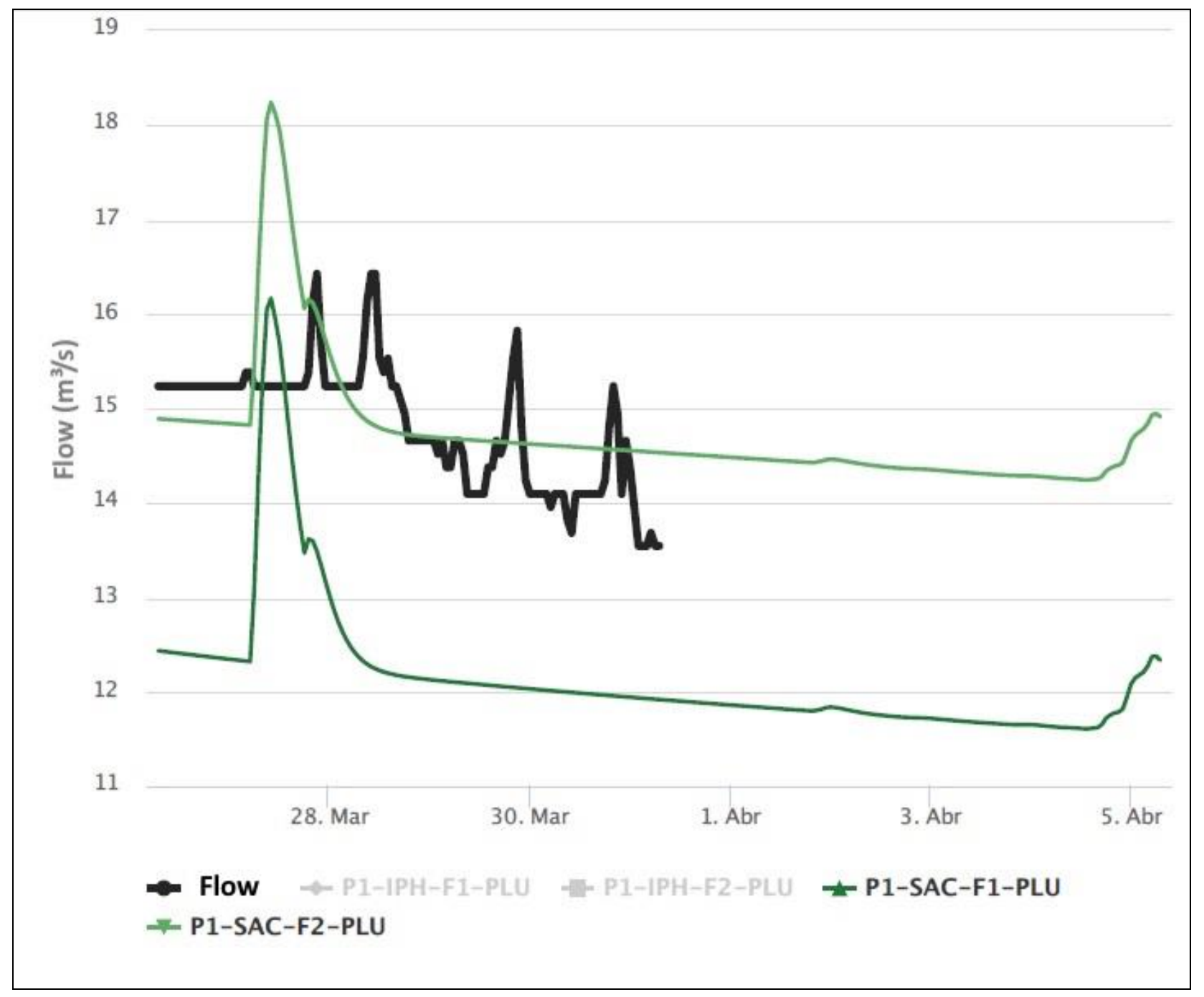

Source: SANEPAR, 2017 
The abbreviations for the parameters used in the model has the following meanings: P1 means "Pirapo", the main river for the catchment of water that supply the city of Maringa and where is located the water treatment plant; SAC and IPH refer to the hydrological model applied in the project - Sacramento Soil Moisture Accounting Model (SAC - SMA) and Instituto de PesquisasHidrológicas (IPH) respectively; F1 and F2 are different parameterizations of the models, used for the optimization calibration of the mathematical models; PLU represents "precipitation", which is estimated from a spot metering by a rain gauge station also called by pluviometer.

According to the graph above, there are 2 parameters that are considered to the stream flowprediction, P1-SAC-F1-PLU and P1-SAC-F2-PLU, while the parameters P1IPH-F1-PLU and P1-IPH-F2-PLU are hidden for bringing distant results when compared to the real flow values. Besides this, the results modelled by the chosen parameters do not perform similar values to the real ones, and that is because the project is still being developed. It means that the project is still in the modelling phase, and there are still possible monitoring and adjustment in the parameters to bemade, and that are necessary with the purpose of obtaining a better mathematical representation of the hydrological model used by SIMEPAR.

Another visit to the concessionaire was made in November 2017, in order to examine the development of the alert system project. Regarding to the adopted model, the parameters were adjusted and the curves were calibrated, however, the resulted graph showed a divergence in the generated results, according to figure 05. Because of this, besides the parameters applied during the development of the project, P1-SAC-F1-PLU and P1-SAC-F2-PLU, others parameters were incorporated, with the purpose of representing in a trustworthy way the real flow values. 
Figure 05 -Real flow and predicted flow data by different parameters used in the hydrological model, and precipitation data

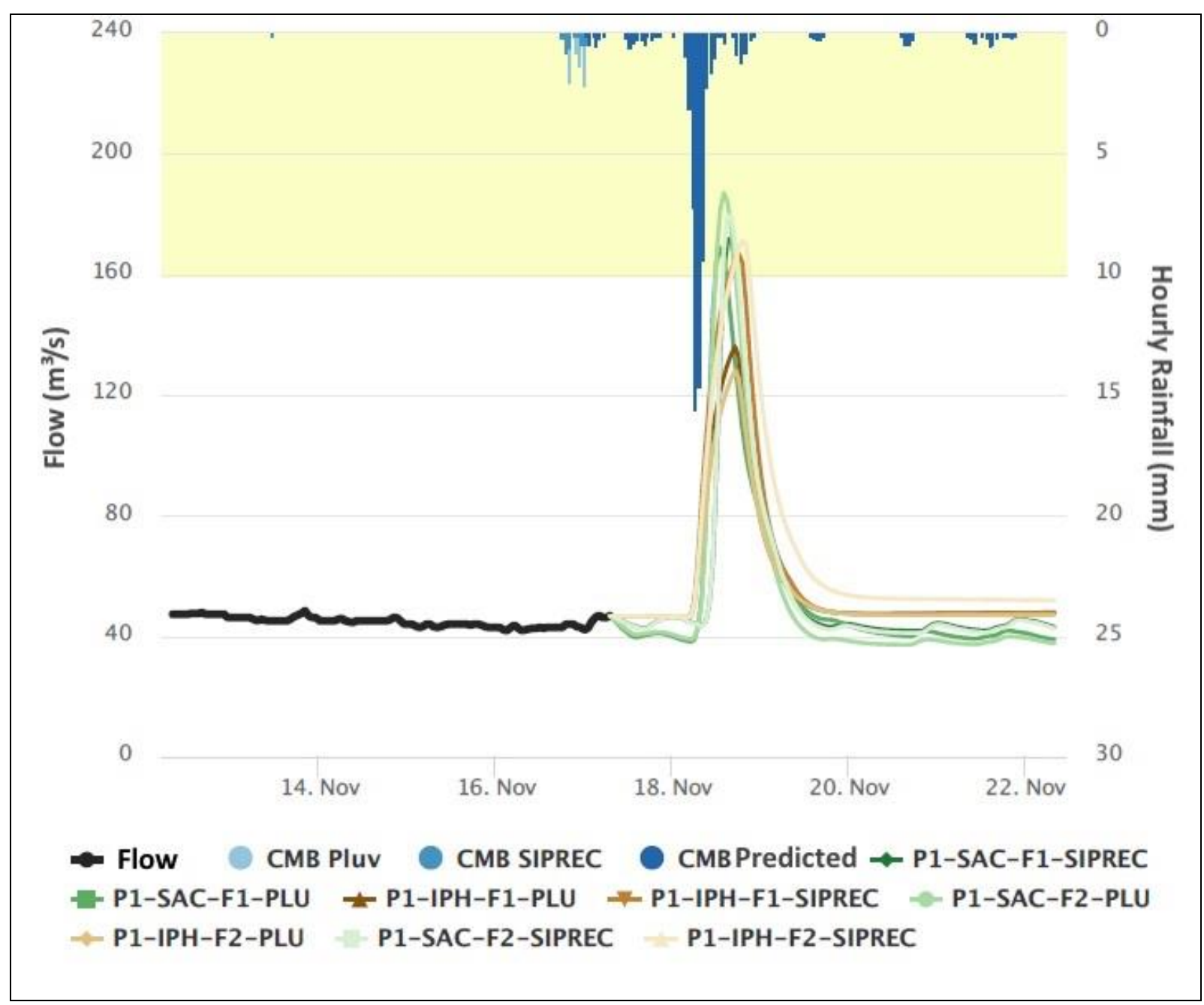

Source: SANEPAR, 2017

The expected precipitation, as shown in figure 05 , is approximately $15,5 \mathrm{~mm}$, and the behaviour of the curves show a peak prediction for all parameters, demonstrating the good fit of the calibrated model to cohesive data. Moreover, comparing the graph of figure 05 to the modelled graph of figure 03 , it is possible to evaluate the similarity of the curve pattern from the precipitation forecasting in the studied basin. Therefore, the hydrological model applied in the flood alert system project of SANEPAR, together with SIMEPAR, is acceptable in view of the satisfactory results in line with the preproject.

The obtained data from the system is copied to a table, available in the webpage of SANEPAR, containing the date and time of the flow rate, that might be the observed 
or the predicted one, which are updated hourly, as shown in table 01. Thus, it is possible to compare the responses and evaluate the real and defined values, validating that the results are in accordance with the predicted model from SIMEPAR.

The table can be of great use for the planning of the public water supply, since from the predicted values of the hydraulic modelling, the concessionaire is capable of preventing and thinking in solutions to avoid possible disorders caused by the rain. From the table, SANEPAR proposed a solution creating an "alert levels" system, related to the intensity of rainfall in the area, classifying the alert levels of the company according to the precipitation rate interval for Maringa. For each alert level, there are internal groups for the solution of some type of trouble associated with the water load, and in emergency cases, the concessionaire must contact the fire department and civil defence to help them with appropriate solutions to the problem caused by heavy rainfall.

The usage of information and communication technology for the system projected by SANEPAR and SIMEPAR seeks to make public water supply planning smarter and more efficient, creating a flood alert system. Installed the sensor in the section of Pirapo river, it was possible to collect fluviatile and pluviometric data and to send real time results to the concessionaire data centre by telemetry, using ICT for real time processing and visualization of the results.

Table 01 - Observed and predicted flow rate for different parameters of the flood alert system project model

\begin{tabular}{lccccc}
\hline Date and time & $\begin{array}{c}\text { Observed flow } \\
\text { rate }\left(\mathrm{m}^{3} / \mathrm{s}\right)\end{array}$ & $\begin{array}{c}\text { Flow rate P1- } \\
\text { SAC-F1-SIPREC }\end{array}$ & $\begin{array}{c}\text { Flow rate P1- } \\
\text { SAC-F1-PLU }\end{array}$ & $\begin{array}{c}\text { Flow rate P1- } \\
\text { IPH-F1-PLU }\end{array}$ & $\begin{array}{c}\text { Flow rate P1- } \\
\text { IPH-F1-SIPREC }\end{array}$ \\
\hline $\begin{array}{l}17 / 11 / 2017 \\
06: 00\end{array}$ & 46,187 & - & - & - & - \\
\hline $\begin{array}{l}17 / 11 / 2017 \\
07: 00\end{array}$ & 46,743 & 46,743 & 46,743 & 46,743 & 46,743 \\
\hline $\begin{array}{l}17 / 11 / 2017 \\
08: 00\end{array}$ & - & 46,382 & 45,528 & 46,723 & 46,739 \\
\hline
\end{tabular}


Continuation...

\begin{tabular}{lccccc}
\hline Date and time & $\begin{array}{c}\text { Observed flow } \\
\text { rate }\left(\mathrm{m}^{3} / \mathrm{s}\right)\end{array}$ & $\begin{array}{c}\text { Flow rate P1- } \\
\text { SAC-F2-PLU }\end{array}$ & $\begin{array}{c}\text { Flow rate P1- } \\
\text { IPH-F2-PLU }\end{array}$ & $\begin{array}{c}\text { Flow rate P1- } \\
\text { SAC-F2-SIPREC }\end{array}$ & $\begin{array}{c}\text { Flow rate P1- } \\
\text { IPH-F2-SIPREC }\end{array}$ \\
\hline $\begin{array}{l}17 / 11 / 2017 \\
06: 00\end{array}$ & 46,187 & - & - & - & - \\
\hline $\begin{array}{l}17 / 11 / 2017 \\
07: 00\end{array}$ & 46,743 & 46,743 & 46,743 & 46,743 & 46,743 \\
\hline $\begin{array}{l}17 / 11 / 2017 \\
08: 00\end{array}$ & - & 45,776 & 46,739 & 46,367 & 46,731 \\
\hline
\end{tabular}

The smart monitoring system, along with the hydrological simulation adopted in this study case, according to Ye et al. (2016), is important in the monitoring of hydrological data, responsible for the safety of the water network system. Moreover, the system architecture includes detection, simulation, diagnosis, anticipated warning, adjustment, disposal and smart control. With the collection of precipitation and water level records, it was established the hydrological models capable of creating scenarios for the understanding and prevention of water flow in Pirapo river basin.

In order to deliver more accurate simulations, model adjustments and parameters calibration were made necessary, and the quantitative prediction of flow rate for the following days is expected to perform a better modelling. In case of rainy forecast for the area, the alert level system in SANEPAR is activated, and as an automatic system, it relates the amount of expected rainfall with each of the alert levels, allowing a better range of adjustments and measures to be taken avoiding catchment problems.

The company has sensors installed in the end of the network, where in general lower pressures are expected, and has a control and operation centre, that allows the intervention in the network, in case it is made necessary. For this, two professionals, one technician and one engineer, must always be present in the centre, being directly involved in the continuous monitoring of the system and remotely monitoring the reservoirs water levels, intervening in case of a need for a better network control.

Therefore, besides smart monitoring of hydrological data in the catchment place, hydrological simulation of precipitation-flow conversion, river hydrodynamics, and yet the transmission of smart data by information and communication technology, 
Parana Sanitation Company has an intelligent monitoring in the reservation and distribution network of clean water, which characterises a smart potable water supply system.

\subsection{Recommendations and new solutions}

An important question when considering management, control and operation of water supply network is the smart monitoring of field data. A programme of collection of data includes specific or permanent monitoring of the hydraulic characteristics, as pressure, flow rate and quality parameters, however, the challenge is to determine the number and location for the quantitative and qualitative data acquisition automatic sensors (data loggers).

A computer program project, proposed by Wu et al. (2015), optimizes the location of the pressure gauges, of the water quality sensors the the selection of hydrants for flow tests. The results show an easy to use prototype and efficient methodology for the development of a technically consistent program for field data collection.

Gurung et al. (2016) demonstrate empirically how the implementation of different potable water economy meters could affect the supply network project. In this regard, an innovative approach was applied in the development of demand profiles, based in intelligent meters, that allow the acquisition of a complete water consumption data set, as shower and sink demands. The meters were installed and the data collected fortnightly, in seven periods between 2010 and 2012. The horizontal planning scenarios were simulated in order to determine the scaling of required expansions in the water supply system. As a result, the enhancements could be delayed, and in some places even avoided, apart from reductions in the necessary infrastructure sizing, when compared to a scenario dimensioned with standards coefficients from the literature for the highest rate of consumption.

\section{Final considerations}


Based on studies regarding the Information and Communication Technology, along with the project conducted by Parana Sanitation Company and Parana Meteorologic System, it is possible to verify in the municipality of Maringa the effort of using this new technology. In the project, the technology is included in the qualitative and quantitative forecasting of precipitation in Pirapo river basin, since this information is essential to the potable water supply planning for the city, applying concepts of smart cities in the water management of Maringa.

Therefore, it can be concluded that the concept of smart cities in the water and sanitation sector is efficient in improving the efficiency of water supply systems in major cities. Moreover, Maringa may be considered as a smart city regarding to monitoring and forecasting of floods in the public water catchment, in a innovative way for this sector.

However, it is recommended studies for the implementation of new alternatives, aiming a more intelligent water supply system, resulting in greater economy and a higher efficiency in the operation. Lastly, it is suggested for future work the evaluation of the reservation, network and sewage systems.

\section{Acknowledgements}

Authors acknowledge Parana Sanitation Company (SANEPAR) by its helpfulness and for the information provided during this study, and Araucaria Foundation by the granted scientific initiation scholarship.

\section{References}

ABDALA, L. N.; SCHREINER, T.; COSTA, E. M. D.; SANTOS, N. D. (2014). Como as cidades inteligentes contribuem para o desenvolvimento de cidades sustentáveis? Uma revisão sistemática de literatura. International Journal of Knowledge Engineering and Management, v. 3, n. 5, p. 98-120.

ALMEIDA, L.; SERRA, J. C. V. (2017). Modelos hidrológicos, tipos e aplicações mais utilizadas. Revista FAE, v. 20, n. 1, p. 129-137. 
BONOTTO, G.; FOGLIATTO, F. S. (2015). Previsão de demanda a partir de métodos quantitativos aplicada ao setor varejista. Universidade Federal do Rio Grande do Sul. URL:

https://www.lume.ufrgs.br/bitstream/handle/10183/147496/000999425.pdf?sequence $=1$. Accessed in: 4 set. 2018 .

CADERNO FGV PROJETOS. (2015). Cidades Inteligentes e Mobilidade Urbana. Rio de Janeiro,

24.URL:https://fgvprojetos.fgv.br/sites/fgvprojetos.fgv.br/files/cadernos_fgvprojetos_s mart_cities_bilingue-final-web.pdf. Accessed in: 29 ago. 2018.

CURY, M. J. F.; MARQUES, J. A. L. F. (2017). A cidade inteligente: uma reterritorialização. Desenvolvimento Regional, v. 22, n. 1, p. 102-117.

DURAN, J.; PEREZ, V. (2015). Smart, innovative and sustainable cities for the future income: Caracas city. $35^{\text {th }}$ Central American and Panama Convention, Institute of Electrical and Eletronics Engineers, Tegucigalpa, Honduras.

ELKINGTON, J. (1999). Triple Bottom Line Revolution: Reporting for the Third Millennium. Australian CPA.

EREMIA, M.; TOMA, L.; SANDULEAC, M. (2017). The Smart City Concept in the 21st Century. $10^{\text {th }}$ International Conference Interdisciplinarity in Engineering, Elsevier, TarguMures, Romania.

GIL, A. C. (2010). Como elaborar projetos de pesquisa. São Paulo: Atlas.

GURUN, T. R.; STEWART, R. A.; BEAL, C. D.; SHARMA, A. K. (2016). Smart meter enabled informatics for economically efficient diversified water supply infrastructure planning. Journal of Cleaner Production, v. 135, p. 1023-1033.

HARRISON, C.; DONNELLY, I. A. (2011). A theory of smart cities. $55^{\text {th }}$ International Society for the Systems Sciences, University of Hull Business School, Hull, United Kingdom.

HERNANDEZ, M. G. (2018). Building a Smart City: Lessons from Barcelona. Communications of the ACM, v. 61, n. 4, p. 50-57.

IBGE, Instituto Brasileiro de Geografia e Estatística. Informações estatísticas. (2012). URL: <http://www.cidades.ibge.gov.br>. Accessed in: 08 set. 2018.

MENEGUETTI, K. S. (2009). Cidade-Jardim, Cidade Sustentável: a estrutura ecológica urbana e a cidade de Maringá. Maringá: Eduem. 
SOUZA, W. V. D. Aplicações do modelo SWAT no Brasil: revisão e estudo de caso Amazônia [monograph]. Minas Gerais: Departamento de Engenharia Sanitária e Ambiental/UFJF; 2016. 40f.

United Nations, World Population Prospects. (2015). The 2015 Revision: Key Findings and Advance Tables.

United Nations, World Urbanization Prospects. (2014). The 2014 Revision: Highlights.

WEISS, M. C.; BERNARDES, R. C.; CONSONI, F. L. (2015).Cidades inteligentes como nova prática para o gerenciamento dos serviços e infraestruturas urbanos: a experiência da cidade de Porto Alegre. Revista Brasileira de Gestão Urbana, v. 7, n. 3, p. 310-324.

WU, Z. Y.; SONG, Y.;ROSHANI, E. (2015). Software prototype for optimization of monitoring and data logging in water distribution systems. Procedia Engineering, v. 119 , p. 470-478.

YE, Y.; LIANG, L.; ZHAO, H.; JIANG, Y. (2016). The System Architecture of Smart Water Grid for Water Security. Procedia Engineering, v. 154, p. 361-368. 